Nesreen. M. El.Said Ali, Samia.A.Al-Askalany, and Hana.M.Ghandor.

\title{
Evaluation of Sensory, Physicochemical Changes of Marshmallow (Children Candy) by Addition Natural colors
}

\author{
${ }^{1}$ Nesreen M El. Said Ali, ${ }^{1}$ Samia A Al-Askalany, and ${ }^{2}$ Hanan M
}

Ghandor

${ }^{1}$ Food Tech. Res. Inst., Agric. Res. Center, Giza, Egypt.

${ }^{2}$ Region Center for Food and Feed, Res. Center, Giza, Egypt.

\section{ABSTRACT}

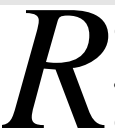

ecent consumers want healthy foods that provide phytonutrients to promote good health and well-being without sacrificing taste, texture. This research was

conducted to diversification of candies; it was intended to valorificationa raw material such as golden berry (Physalis peruviana) juice and red beet root (Beta vulgaris rubra) puree/juice to make marshmallow candy. A marshmallow is a light, fluffy sweet made by beating air into a sugar solution containing gum (eg gelatine), color and flavor, beating air into the gelatine solution produces a structure, with smaller air bubbles. The gelatine will eventually harden and in so doing will trap the air that has been added to the mixture. The resulting product is spongy and slightly rubbery. A spongy marshmallow is a sugar-based confection that, contain (sugar, water and gelatin) molded into small cylindrical pieces, and coated with corn starch. This confection is the modern version of a medicinal confection made from Althaea officinalis,. This research has been producing (soft candy) marshmallows by using natural sources for both of color and flavor such as golden berry and red beet-roots. Finally, it could be clearly concluded that, it is proper, successful, economic and applicable to produce two kinds of marshmallows with natural color and flavor which are very suitable to be taken as a good natural confectionery of healthy food coloring. The use of natural anthocyanin dyes in marshmallow technology allows increasing the antioxidant properties of the final product. The value of the antioxidant capacity for all of samples was content of antioxidant activity (32.76\%-44.87\%) higher than that of the sample were made without the dyes or artificial dyes. The results of sensory evaluation demonstrated that, there was no significant difference in [taste and also color followed by acceptability and odor] between the control sample marshmallow with (artificial colors/flavor) and the suggestion marshmallow samples [fruit (golden berry)/vegetable (red beet-roots)] marshmallow.

Key words: Marshmallow (soft candy), natural color/flavor, red beet-root (Beta vulgaris rubra) juice/puree, golden berry (Physalis peruviana) juice. 
Nesreen. M. El.Said Ali, Samia.A.Al-Askalany, and Hana.M.Ghandor.

\section{INTRODUCTION}

Marshmallow probably first came into being as a medicinal substance, since the mucilaginous extracts come from the root of the marshmallow plant, Althaeaofficinalis, which was used as a remedy for sore throats. Marshmallow works as mucilage, producing a thick sticky substance that coats membranes. It extract contains flavanoids, which contain anti-inflammatory properties. The flavanoids are able to reduce inflammation while the mucilage holds them in place and prevents further damage by inducing phagocytosis, which is the process in which certain cells engulf bacteria, dead cell tissues or other solid particles. This helps speed up the healing process. The extracts also this is" Originally 'marshmallows' were used for medicinal purposes. Marshmallow probably first came into being as a medicinal substance, which was used as a remedy for sore throats. The root has been used since Egyptian antiquity in a honeysweetened confection useful in the treatment of sore throat (www.Herbwisdom.

com/Marshmallow/Althaea or
marshmallow-knowledge encyclopedia). Nowadays, marshmallow is an aerated confectionery product with a characteristic foamy structure created when air and moisture is incorporated into a syrup mixture. The air increases the volume of the marshmallow and is responsible for its fluffy texture (Jackson, 1990).The basic ingredients in marshmallow are sucrose, glucose syrup, water, color and/or flavor, and whipping agents. A variety of whipping agents can be used either individually or in combination with other ingredients, such as egg albumen, gelatine, pectin, agar, and starch, to help produce a stable foam structure (Jackson, 1990 and Kaletunc et al., 1992). In the confectionery industry, marshmallow is prepared by heating base syrup, which evaporates water to achieve an optimal concentration. The mixture is cooled to a predetermined temperature and a whipping agent is added prior to beating. Depending on the texture required, the moisture content of marshmallow can vary between 17 and $21 \%$, and the density can vary between 0.25 and $0.50 \mathrm{~g} / \mathrm{ml}$ (Jackson, 1990). Human nutritional research is continually showing that a wellbalanced diet, rich in fruits and vegetables, promotes good 
health and may reduce the risk of many dangerous diseases (Catunescu et al., 2012). Candy is one of most popular foods among a lot of people from wide ranges of age. Confectionery products are food formulations characterized by aqueous dispersions of sugar syrups and are available in a broad variety of forms including caramels, marshmallows, gums, jellies and gummies, and hard candies. Soft jelly is characterized by a soft and chewy texture typically conferred by a gelatin or pectinbased gel (Fisher, 2011). Utomo et al. (2014) stated that chewy candies made with different gelling agents and sweetener suffers certain/specific texture characteristics and eating properties. It is known that, red beet-roots and golden berry contain a high amount of nutritional composition and bioactive components as a health promoting functional food. These raw materials was chosen in obtaining soft candy for several reasons including: a specific taste, a natural color given by the pigments (carotene and anthocyanin), which offers the soft candy a natural and pleasant texture. Marshmallows are a type of confectionary product known for its soft, foamy texture. It owes this characteristic to its relatively high moisture content (17\%$21 \%$ by wt.,) and porous structure. However, these attributes make marshmallows more susceptible to quality degrading changes such as; sugar crystallization, texture aging, foam collapse and hardening or softening. The high interfacial area, increases the rates of mass transfer which makes it harder for marshmallows to preserve its initial moisture content in humid or dry environments (Kirtil et al., 2017). Marshmallows have a short shelf life compared to other confections because of their unstable foamy gel structure, high moisture, and large air interfacial surface area. The degradation of marshmallow may be caused by several physicochemical changes, including moisture loss, sugar crystallization, foam collapse, or texture aging 
Nesreen. M. El.Said Ali, Samia.A.Al-Askalany, and Hana.M.Ghandor.

(Tiemstra, 1964; Lees and Jackson, 1973; Howling and Jackson, 1990). Water in confections is necessary for processing of raw materials into final products. It affects product texture and is one of the primary factors affecting shelf life and also, the one of the main functions of water in confectionery formulas is to dissolve and prepare [the slurry of sugar and corn (glucose) syrup] for the ingredients as well as help mixing. Depending on the method of cooking, the most candies were between 20 and $35 \%$ of water by weight of sugar solids is required to dissolve the slurry. In sugar-based confections, the water content is generally governed by the boiling point relationship of the sugars present in the formulation. The final water content has a significant impact on texture and shelf life, with lower moisture content leading to harder confections that typically have longer shelf life. However, water content by itself is not sufficient to completely characterize candy quality and shelf life. Water activity, or the relative vapor pressure, of the confection is an important parameter often used to describe microbial stability, texture, and water migration during storage (Ergun et al., 2010). It is now generally accepted that $\left(a_{w}\right)$ is more closely related to the physical, chemical, and biological properties of foods and other natural products than is total moisture content. Specific changes in color, aroma, flavor, texture, stability, and acceptability of raw and processed food products have been associated with relatively narrow $\left(\mathrm{a}_{\mathrm{w}}\right)$ ranges, (Rockl and Nishi, 1980). Gelatin is a protein. It consists of 84 to $90 \%$ protein and approximately $1 \%$ of mineral salts, the rest being water. Gelatin in a highly purified form is a fascinating substance for food and recognized to have thickening, jellifying, foaming, viscosity enhancing, binding, emulsifying, and many more functions. It is also much used for its pharmaceutical, and technical applications; but gelatin remains an essential ingredient in the food industry (www. 
Nesreen. M. El.Said Ali, Samia.A.Al-Askalany, and Hana.M.Ghandor.

halalexpertise.com/gelatin). The development of new jellies products with carrots and strawberry can be an alternative for high-quality candy products that meet consumer demands. Given the natural color from the red pigment anthocyanin and orange pigment carotene, jellies have a natural look pleasant, attractive to the consumer. Due to the high vitamin $\mathrm{C}$ content, the products obtained address all categories of consumers (LianaClaudia et al, 2015). The antioxidant capacity and total phenolic contents of fruits were found to be $57.67 \%$ and $145.22 \mathrm{mg}$

$\mathrm{GAE} / 100 \mathrm{~g}$, respectively. In addition to fruit general nutritional properties, golden berry is attracting interest for potential health benefits due to their biologically active compounds (Gökçen, 2015). Cape golden berry ( $P$. peruviana Linn.,Solanaceae) has been grown in Egypt, SouthAfrica, India, New Zealand, Australia and Great Britain [Mc Cain,(1993), Ramadan, and Mörsel (2003), Rehm, and Espig (1991)]. Berries have been shown to provide significant health benefits because of their high antioxidants, vitamins, minerals and fiber (Zhao, 2007). The well-documented health benefits of a diet high in fruits and vegetables have led to a growing interest in so-called "functional foods" and their application in health and disease. In recent years, the root vegetable (Beta vulgaris rubra), otherwise known as red beet-roots (herein referred to as beet roots) has attracted much attention as a health promoting functional food (Ninfali, and Angelino, 2013). This is the powerful antioxidant responsible for the beet's vibrant color. The main benefits associated with golden berry (Physalisperuviana), are its nutritional composition and bioactive components and a promising exotic fruit that could be a subject of many novel foods. Golden berry juice showed lower levels of total cholesterol, triacylglycerol and low-density lipoprotein cholesterol and its juice is rich in water and fat-soluble bioactive compounds and could be a novel source of functional drinks 
Nesreen. M. El.Said Ali, Samia.A.Al-Askalany, and Hana.M.Ghandor.

(Otakar et al., 2012). The purpose of this review is to study natural sources as well the nutritional, phytochemical, and antioxidant such as golden berry (Physalisperuviana) and red beet-roots (Beta vulgaris rubra) are a promising exotic fruit and vegetable, that could be a subject of many novel foods. For the time being, looking for new food resources with antioxidant properties is one of the priorities in the food industry (Kyzlink1990). A great advantage of Cape gooseberry is that the fruits can be consumed fresh so that it is not necessary to cook or otherwise treat them. The quality of Cape gooseberry fruit is considerably influenced by preservation and other methods of technological treatment and its antioxidant efficiency can therefore be reduced (Velisek, 2002). Besides, the benefits of antioxidant properties for the human body it is also necessary to consider the impact of antioxidants on the shelf life. Based on the available data, red beetroot appears to be a powerful dietary source of health promoting agents that holds potential as therapeutic treatment for several pathological disorders. In the human studies to date, beetroots supplementation has been reported to reduce blood pressure, attenuate inflammation, avert oxidative stress, preserve endothelial function and restore cerebrovascular hemodynamics (Tom et al., 2015).

Thus the aim of the current investigation was to evaluate and use some fruits or vegetables in soft candies (marshmallows), by physicochemical analyses, physical parameters and general consumer's acceptance, to achieve the proposed goal for two kinds of colors red and yellow with (red beet- roots juice/puree and golden berry juice).

\section{MATERIALS \& METHODS}

\section{Materials:}

All these raw materials used in these experiments have been purchased from a local market as fresh for both of vegetable and 
Evaluation of Sensory, Physicochemical Changes of Marshmallow (Children Candy) by Addition Natural colors

Nesreen. M. El.Said Ali, Samia.A.Al-Askalany, and Hana.M.Ghandor.

fruit included red beet-roots (Beta vulgarisrubra), golden berry (Physalisperuviana). Artificial marshmallow was purchased from local supermarkets in Giza,(Egypt).

\section{Methods:}

Preparation of each natural extracts:

Red beet- roots, and golden berry, were washed and squeeze. Each of extracts was filtered; golden berry is used in juice form. Also, the other form for red beet-roots was prepared in juice by carrot juicer and purees form after boiling until it becomes soft, and then mixed with hand blender. Knowing that, golden berry used as the main component for both of three types marshmallows as following; [golden berry (100\%)] and in both form red beet-roots juice/ puree [golden berry $(50 \%) /$ red beet-roots $(50 \%)]$.

Process and Preparation of Natural for marshmallows:

The product contains as following ingredients:red beetroots juice/ puree orgolden berry juice (100ml),coarse sugar (360g), golden syrupor[corn(glucose)syrup](140 gm), gelatin(25g), vanilla,confecti oners(powdered)sugar,andcorn starch or (corn flour).

Main Physical Parameters and Chemical Composition of marshmallows (soft candies):

The physicochemical analyses of samples were analyzed according to standards of AOAC (Association, 2012). The method was for determination of moisture content, crude fiber, total sugar contents, and sucrose.

Non- enzymatic browning [Color index at 420nm)]:

The increase in absorbance of a sample extract at $440 \mathrm{~nm}$ is taken as a measure of non-enzymatic browning. The color also is measured at $420 \mathrm{~nm}$. Extract 4-5 gm of sample with $100 \mathrm{ml}$ of $60 \%$ alcohol for $12 \mathrm{hr}$. and filter. For sample containing chlorophyll, shake the alcoholic extract with three lots of $50 \mathrm{ml}$ benzene. If the filtrate is not clear, will be refilled using filter aid. Measure the color at $440 \mathrm{~nm}$ 
Evaluation of Sensory, Physicochemical Changes of Marshmallow (Children Candy) by Addition Natural colors

Nesreen. M. El.Said Ali, Samia.A.Al-Askalany, and Hana.M.Ghandor.

using $60 \%$ aqueous alcohol as blank, according to Ranganna, (1977).

\section{Color Identification:}

Spectrophotometer"6705 $\mathrm{UV} / \mathrm{V}$ is Spectrophotometer JENWAY" was used for the measurement of color intensity at different wave lengths ranging between 400-700 nm., according to Ranganna (1977).

\section{Antioxidants Activity (DPPH $\%)$ :}

Anti-oxidant activity was determined by DPPH method according by Brands, Williams (1995).

\section{Physical Properties:}

Textural Attributes such as texture profile parameters (Hardness,

Cohesiveness, Springiness, Gumminess and Chewiness).

Texture profile analysis test of samples ( which shape was $3 \times 3 \times 3$ cylindrical) was done using a Universal Testing Machine (TMS-Pro) Food Technology Corporation, Sterling, Verginia, USA) equipped with $1000 \mathrm{~N}$ (250 lbf) load cell and connected to a computer programmed with Texture Pro TM texture analysis software (program, DEV TPA With holding time between cycle two second). A flat rod probes (49.95 $\mathrm{mm}$ in diameter) to uniaxial compresses the samples with the following parameters conduction to $25 \%$ of their original height. Each sample was subjected to two subsequent cycles (bites) of compressiondecompression.

Data were collected on computer and the texture profile parameters were calculated from DEV TPA texture analyzer and computer interface. Calculation described by Szczesniak et al., (1963) and Bourne (1978) was used to obtain the following texture profile parameters (Hardness, Cohesiveness, Springiness, Gumminess and Chewiness).

\section{Water activity $\left(a_{w}\right)$ :}

The major advantages of the chilled mirror dew point method are speed and accuracy. Chilled mirror dew point is a primary approach

to measurement of relative 
humidity based on fundamental thermodynamic principles. Chilled mirror instruments make accurate $\left( \pm 0.003 \mathrm{a}_{\mathrm{w}}\right)$ measurements in less than5 minutes. Since the measurement is based on temperature determination, calibration is unnecessary, but running a standard salt solution checks proper functioning of the instrument. If there is a problem, the mirror is easily accessible and can be cleaned in a few minutes. For some applications, fast readings allow manufacturers to perform at-line monitoring of a product's water activity (Rockland, and Nishi, 1980).

\section{Reconstitution} of marshmallows (soft candies): Reconstitution of marshmallow (soft candies) was determined according to the method stated by Von Loesecke (1955) as following: $10 \mathrm{~g}$ the tested dry material samples were placed in $600 \mathrm{ml}$ pyrex beaker, 80 to $150 \mathrm{ml}$ distillated water were added, covered with a watch glass, placed on electric heater, as boiled for $5 \mathrm{~min}$., removed from the heater and dumped into a 75 min., Buchner funnel which was covered with a coarsely porous filter paper. Suction was gently applied and drained with careful stirring for one min., or until the drip from the funnel has almost stopped. Samples were removed from the funnel and a weighted calculation was made to express in terms of "Reconstitution ration".

Reconstitution ratio $(\%)=$

The drained weight of the reconstitution sample (WR) / the origin weight of the dehydration sample (WD) X 100

\section{Sensory evaluations of Marshmallows product:}

For the sensory analysis a simple hedonic scale with a small number of points (from 1 to 10 with $1-\mathrm{i}$ don't like it and 10 - I like it very much) was used in order to evaluate the first impression, the aspect, the quality attributes (color, taste, flavor, texture, appearance and overall acceptability of the samples of soft candies compared with artificial marshmallows (control). Using 
Nesreen. M. El.Said Ali, Samia.A.Al-Askalany, and Hana.M.Ghandor.

suggested was evaluated for their sensory characteristics by ten panelists from the staff of the Processing Crops, Research Dep., Agric. Res. Center, Giza. Acceptability is giving numerical scores to each of their attributes from 10 panelists. The produced was organoleptically judged by groups of panel testers. The quality was scored on a scale (1 to 10). The following scale was applied to all samples for color, taste, flavor, Texture, Appearance, and overall acceptability as follows:

Excellent $=(10), \quad$ Very good $=(8-9)$, Palatable $=(6-7)$, and Unpalatable. $=(0-5)$.These proportion were scored on a scale from 1-10 according to Watts et al.,(1989).

\section{Statistical analysis:}

Data were analyzed by Analysis of Variance using General Liner Model (GLM) procedure according to the procedure reported by Sendecor and Cochran (1997). Means were separated using Duncan's test at a degree of significance $(\mathrm{P} \leq 0.05)$. Statistical analyses were made using the producer of the SAS software system program (SAS, 1997).Statistical Analysis System. User's Guide: Statistics, SAS Institute Inc, Gary, Nc., USA.

\section{RESULTS \& DISCUSSION}

Marshmallow is a confection of foam-like structure and demand for it is constantly growing on the world markets. Due to the presence of gelatin, it possesses good chewing properties. Although the nutritional value of the main types of marshmallow remains very poor. To ensure high organoleptic characteristics of marshmallow, dyes and flavoring substances are included in the receipts. The most of them are synthetic; therefore a positive impact does not go beyond a good color, taste and smell. Marshmallows are simply described as air bubbles surrounded by sugar syrup. The sugar syrup, made of sucrose, corn syrup, and water, is cooked at appropriate temperature to reach the desired water content, which allows air to be whipped into the matrix by mechanical agitation. During 
whipping, the density of the product decreases as the syrup and foam mixture expands into a light, fluffy marshmallow. Marshmallows may be either non-grained or grained crystal aggregate, depending on the ratio of sucrose to corn syrup Sucharzewska et al., (2003) and Ergun et al., (2010). Color and flavor are becoming the most sensitive qualities for any commodity not for its appeal but also it enhances consumer palatability. In addition, the color of a food substance is important to indicate its freshness and safety that are also indices of good aesthetic and sensorial value. For natural color and additives adherence to the norms of bio-safety protocol are limited. The demand for natural color source of such compounds is increasing day by day because of awareness of positive health benefit out of natural compounds as powerful antioxidants pigment/ flavor. It therefore, necessitates looking into natural sources of food grade colorants / flavors and their use potentials as well red beet root for red color and golden berry for yellow color/ flavor. At present, Cape gooseberry (Physalisperuviana) fruit is one of the less used raw materials of plant origin, which can be used for human nutrition. This fruit, as well as alimentary products made of it, were used by healers in folk medicine in the distant past. Table (1) shows that, some main physical parameters and chemical composition which determined of the new types of (soft candies) or marshmallows products also, and called in this case (fruit marshmallow), what made of fruit puree/juice. We can see from Table(1) moisture content for marshmallow with natural anthocyanin dyes is within11.85 -16.08 \%, total solids is $88.15-83.92$, sucrose content does not exceed $4.41 \%$ and total sugars is within 10.81$12.42 \%$ of the new types for natural dye marshmallows. The data from table (1) proved that, the use of natural dyes in marshmallow technology has stated that, for color index; yellow color 0.355 compared with 1.805 as control, and red color $[(0.0 .085 / 0.284)]$ with 0.119 as control. Identification 
colors; natural yellow color was $0.084(419 \mathrm{~nm})$ compared with control

$$
\text { [1.918(433nm)/2.487(302nm)] }
$$

followed by also, natural red color $[0.470(540 \mathrm{~nm})$ in red beet-roots (juice), and $0.180(547 \mathrm{~nm})$ in red beet-roots (puree) compared with control $[0,290(513 \mathrm{~nm})]$ as well as fibers was equal $0.0 \%$, Artamonova et al., (2017). It is important to study natural anthocyanin dyes to produce high-quality marshmallow with improved food value and natural colors. Realization of the idea will let to expand the marshmallow range and create competitive products on the confectionery market. Wearer actively is developing new marshmallow technologies for special purposes with the use of natural raw materials.

The results recorded in Table (2) showed that total antioxidants activity on (fresh weight basis) and Minerals on dry basis in Marshmallows. Treatments which contain fruit and vegetables have high content of antioxidant activity especially in golden berry (44.87\%) and red beet-roots (puree) $41.21 \%$.
The lowest antioxidant activity was observedin imported control (1) $30.53 \%$ while blank (36.23\%) and local control (2) $32.57 \%$, were related to other three treatments. Those results indicated that golden berry juice and red beet-roots (juice/puree) contain high amounts of natural antioxidant and phytochemical substances may be increased antioxidant activity in Marshmallow OtakarRop et al., (2012) and Tom Clifford et al., (2015). Minerals contents showed that local cont., (2) had highest content from calcium $(726.4 \mathrm{mg} / \mathrm{kg}$ ) and selenium $(7.067 \mathrm{mg} / \mathrm{kg}$ ) while blank had the highest content of Fe (115.3 $\mathrm{mg} / \mathrm{kg}$ ). Treatment of red beetroots (puree) showed the higher content from (Si $0.074 \mathrm{mg} / \mathrm{kg}$, $\mathrm{Fe} 90.035 \mathrm{mg} / \mathrm{kg}$ and $\mathrm{Ca} 319.8$ $\mathrm{mg} / \mathrm{kg}$,) respectively. in comparing with golden berry and red beet-roots (juice). The lowest content of minerals was in treatment of imported cont., (1) as following; [Si $1.076 \mathrm{mg} / \mathrm{kg}, \mathrm{Fe} 67.8 \mathrm{mg} / \mathrm{kg}$ and Ca202.9 mg/kg] respectively. The highest ratio of calcium and iron in Marshmallows may due 
Nesreen. M. El.Said Ali, Samia.A.Al-Askalany, and Hana.M.Ghandor.

is return to gelatin components extraction (Mischel et al., 2011).

Ergun, et al., (2010) mentioned that, water is one of the most important components of confections. The nature of water bonding with food components and its interaction with the surrounding atmosphere affects the physical or textural characteristics of the food product as well as the food's shelf stability. The present study understanding of the behavior of water in confections has grown. Progressing from is used of water content to water activity, to the principles of water mobility. One of the main functions of water in confectionery formulas is to dissolve the ingredients and help with mixing. In most candies, the water is used to dissolve and prepare the slurry of sugar and corn (glucose) syrup. Marshmallows may be either ungrained or grained, depending on the ratio of sucrose to corn syrup. Water content affects marshmallow hardness and flow properties.

Ungrained marshmallows typically have moisture content of $15-18 \%$. A fresh-made, ungrained marshmallow has fairly high $\mathrm{a}_{\mathrm{w}}$, above 0.7, dependent on moisture content and composition it is. From Table (3), it is shown that, Physical Properties -texture attributes such as (Hardness, Cohesiveness, Springiness, Gumminess, and Chewiness). Physical structure is often altered by changes in water activity due to moisture gain resulting in a transition from the rubber to the glassy state. On the other side also, reveal that, there is a reverse relationship between marshmallow products hardness and its water content in Table (3), when fresh and throughout the ripening period, From these results which are shown in Table (3) the hardness attribute for imported marshmallow cont., (1) was the best followed by the marshmallow sample of the golden berry, but the lowest sample of marshmallow red beet-roots (puree) Johanna and Miang, (2008). Cohesiveness; there is no significantly different between golden berry, blank, 
and local cont.,(2) marshmallow that, had represented the lowest values was the best followed by imported cont.,(1). On the other side, the highest values are red bee-roots (puree) followed by (juice) and imported cot., (1)was the worst quality. Springiness; is blank and golden berry marshmallows compared with local cont., (2) followed by red beet root (juice) are the best with significantly differences between them, but the least one was red beet root (puree) the worst quality. Gumminess; red beet root (puree) was the worst, but imported cont., (1) followed by golden berry, and red beet root (juice) marshmallow were the best. Chewiness; imported cont., (1) followed by blank and golden berry marshmallow also, red beet root (juice) were the best one. On the other side, locally cont.,(2) and red beet root (puree) were the worst by there are significantly different. Water activity $\left(\mathrm{a}_{\mathrm{w}) \text {; }}\right.$ both of golden berry marshmallow and red beet-roots (juice/puree), and blank had the highest values, this indicates the least quality. On the other hand, imported cont.,
(1) and locally cont.,(2) were the lowest values, this means the best. Del PilarBuera, et al. (2006). Lim et al., (2006) studied that, the initial water content of the marshmallow was $19.5 \%$, and though water activity was not measured, it was probably between 0.65 and 0.70 , if not higher. After 20 weeks of storage, the marshmallow water content had decreased to $7.9 \%$ and hardness had increased.

From those results which are shown in Table (4): the rehydration time (every1 hr.,) of water absorbed by control (1) of imported sample marshmallow was increased in its values reconstitution ratio by increasing time of the soaking and supposed to decrease with increasing the rehydration time, while the all of other samples such as blank, golden berry, red beet roots (juice), and red beet roots (puree) respectively., had took to decrease including control (2) of locally sample marshmallow. Results revealed that, reconstitution ratio values for control (2) of locally and blank followed by golden berry 
Nesreen. M. El.Said Ali, Samia.A.Al-Askalany, and Hana.M.Ghandor.

and red beet- roots (juice) were the best with significantly differences between them, but the least one red beet root (puree) was the worst value after ( 2 hrs.,)of the rehydration time, while reconstitution ratio values for blank, control (2) of locally followed by red beet- roots (juice) were also better than golden berry but red beet root (puree) was the worst one after (3 hrs.,) of the rehydration time. Finally, it is noticed that, more than 3 hours ofthe rehydration time had occurred deterioration for reconstitution ratio values of marshmallow samples by increasing time of soaking without any significant differences between them compared with imported control(1) and red beet root (puree) was the worst value, according to Kirtil,et al., (2017).

The data which is cleared in table (5) showed that, no significant difference in color in all suggestion marshmallows. Taste showed no significant difference between imported cont., (1), blank, golden berry and red beet-roots marshmallow (juice), while local cont.,(2) marshmallow recorded the highest score and red beetroots(puree) lowest score. Odor showed no difference between all samples except red beetroots(puree) marshmallow showed lower score, also texture recorded no significant difference between imported control(1), blank, golden berry and red beet-roots root (juice) suggestion samples, except red beet-roots(puree) samples had lowest score. Acceptability had no significant difference in all suggestion samples marshmallow and also, red beetroots (puree) samples were lowest score. In general, it can be concluded that, the lowest scores of the sensory evaluation parameters showed in table (5) suggestion marshmallow which contained red beetroots(puree).It could be observed that samples[blank and golden berry as well as red beet-roots (juice)] suggestion marshmallow respectively., had the same record scores of import control (1) and local control (2) artificial marshmallows in taste and also color followed by acceptability 
and odor, according to[LianaClaudia et al.,(2015), and Eva Ungure et al.,(2013)].

\section{CONCLUSIONS}

From this study, it could be clearly concluded that, it is proper, successful, economic and applicable to produce vegetables and fruits marshmallows covered with the same amount of color and aroma which are given by the artificial colors, hence we must resort to natural sources which are very suitable to be taken as a good natural food or natural-food additive with many categories of healthy foodstuffs. The phytochemical analysis of the marshmallows fruit/vegetables revealed it being a good source of total phenolic and flavonoids. These compounds which are found naturally in fruits/vegetables protect body against free radical, besides improving immune system and also have healthy benefits. The findings showed that, the marshmallow fruits/ vegetables formula covered with the same amount of color given by colors added to the artificial juice hence we must resort to natural marshmallow fruits/ vegetables, this result is nearly due to the high anti-oxidants content, and general consumer's acceptance the products obtained address all categories of consumers.

\section{REFERENCE}

Artamonova M; Piliugina I; Samokhvalova O; Murlykina N; Kravchenko O; Fomina I and Grigorenko A (2017):

A study of properties of marshmallow with natural anthocyanin dyes during storage, Technology and equipment of food production, 3/11, 87 .

\section{Association of Official Analytical Chemists-AOAC (2012): \\ Official Methods of Analysis, Washington: AOAC.}

\section{Bourne M (1978):}

Texture profile analysis, Food Tech., 32, 62

Brands Williams W; Cuvelier $\mathrm{ME}$ and Berset C(1995): 
Evaluation of Sensory, Physicochemical Changes of Marshmallow (Children Candy) by Addition Natural colors

Nesreen. M. El.Said Ali, Samia.A.Al-Askalany, and Hana.M.Ghandor.

Use of a free radical method to evaluated anti-oxidant activity, Lebensittel Wissenchaft Technology, $28,25-30$.

Catunescu CM; Tofana M; Muresan C; Ranga F; David A and Muntean, $M$ (2012):

The effect of cold storage on some Quality Characteristics of Minimally Processed parsley (Petroselinum Crispum), Dill (Anethumgraveolens) and Lovage

(Levisticumofficinale), Bulletin USAMV, Agriculture,69,2:213-221.

Del PilarBuera M; WeltiChane J; Lillford JP and Corti HR (2006):

Food Preservation

Technology Series, (Water Properties of Food, Pharmaceutical, and Biological Materials),CRC Press, Taylor and Francis Group, CRC Press, Website at http://www.crcpress.com

Ergun R; Lietha R and Hartel RW (2010):
Moisture and Shelf Life in Sugar Confections, Journal Critical Reviews in Food Science and Nutrition, 50, 2:162-192.

EvaUngure; Straumîte E; Muipniece-Brasava $S$ and Dukaïska L (2013):

Consumer Attitude and Sensory Evaluation of Marshmallow, Proceedings of the Latvian Academy of Sciences Section B Natural Exact and Applied Sciences, 67, 4/5: 442-447.

Fisher EL (2011):

Physicochemical

Characterization of a Novel Strawberry Confection for Delivery of Fruit Bioactive to Human Oral Mucosa, Thesis, Graduate School of the Ohio State University.

Gökçen Yıldız; Nazmiİzli; HalilÜnal and Vildan-Uylaşer (2015):

Physical and chemical characteristics of goldenberry fruit (Physalisperuviana L.),J.Food 
Evaluation of Sensory, Physicochemical Changes of Marshmallow (Children Candy) by Addition Natural colors

Nesreen. M. El.Said Ali, Samia.A.Al-Askalany, and Hana.M.Ghandor.

Sci.Technol,52,4:2320

2327. marshmallow, J. Texture Stud, 23, 47.
Howling D and Jackson EB (1990):

Sugar Confectionery

Manufacture, E.B. Jackson, ed., Blackie and Son Ltd, New York, $34-56$.

\section{Jackson EB (1990):}

Liquor ice paste, cream and aerated confectionery, Sugar Confectionery Manufacture, E.B. Jackson, ed., Blackie and Son Ltd, New York, 218 $-236$.

Johanna MT and Miang HL (2008):

Effects of gelatine type and concentration on the shelflife stabilityand quality of marshmallows,

International Journal of Food Science and Technology,43,1699-1704.

Kaletunc G; Normand MD; Johnston EA and Peleg M (1992):

Instrumental determination of elasticity
Kirtil E; Aydogdu A and Oztop M H(2017):

Investigation of physical properties and moisture sorption behavior of different marshmallow formulations, Acta horticulturae, 1152,33:243248.

Kyzlink V (1990):

Principles of food preservation, $1^{\text {st }}$ ed. Elsevier, Amsterdam.

Lees $\mathrm{R}$ and Jackson E.B (1973): Sugars and related materials, Sugar Confectionery and Chocolate Manufacture, Leonard Hill Books, United Kingdom:15 - 46.

\section{Liana-Claudia S; Toeana M; POP C; Socai S; POP A and Nagy M (2015):}

Physicochemical Properties and Sensory Evaluation of Jelly Candy Made from Carrots and Strawberries, Bulletin "UASVM" Food 
Evaluation of Sensory, Physicochemical Changes of Marshmallow (Children Candy) by Addition Natural colors

Nesreen. M. El.Said Ali, Samia.A.Al-Askalany, and Hana.M.Ghandor.

Science

and

Technology,72,1.

\section{LimM.H; Yin J and Heenan S} (2006):

"The mystery of marshmallow hardening". In: Food Preservation Technology Series-Water Properties of Food, Pharmaceutical and Biological Materials, 325342. Beura, P., WeltiChanes, J., Lillford, P. J. and Corti, H. R., Eds. CRC Press, NY.

Mc Cain, R (1993);

Golden berry, passionfruit and white sapote: potential fruits for cool subtropical areas, J. Janick and J.E. Simon (eds.), New crops. Wiley, New York, 479-486.

Mischel W; OzlemAyduk; Marc G; Berman, B. J; Casey, Ian H; Gotlib, John Jonides; Ethan Kross; Theresa Teslovich; Nicole L; Wilson Vivian Zayas and Yuichi Shoda(2011):
"Willpower" over the life span: decomposing selfregulation, SCAN,6, 252256.

Ninfali $P$ and Angelino $D$ (2013):

Nutritional and functional potential of Beta vulgaris cicla and rubra, Fitoterapia,89,188-199.

OtakarRop; Jiri Mlcek; Tunde Jurikova and Magdalena Valsikov (2012):

Bioactive content and antioxidant capacity of Cape gooseberry fruit, Cent. Eur. J. Biol, 7,4,672-679.

Ramadan, MF and Mörsel JT (2003):

Oil goldenberry (Physalisperuviana L.), Journal of Agricultural and Food Chemistry, 51(4), 969-974.

\section{Ranganna SC(1977):}

Manual of analysis of Fruit and Vegetable Products, Tata. McGraw- Hill Publisng Company Limited. 
Evaluation of Sensory, Physicochemical Changes of Marshmallow (Children Candy) by Addition Natural colors

Nesreen. M. El.Said Ali, Samia.A.Al-Askalany, and Hana.M.Ghandor.

Rehm S and Espig G (1991):

Fruit, in The Cultivated plants of the topics and subtropics, Cultivation, Economic value, Utilization, ed. by Sigmund $\mathrm{R}$ and Gustav E. Verlag Josef Margraf, Weikersheim, Germany, 169-245.

\section{Rockland LB and Nishi SK (1980):}

Fundamentals of Water Activity. Food Tech,34,4259.

SAS (1997):

Statistical Analysis System. User's Guide, Statistics, SAS Institute Inc, Gary, Nc., USA.

Sendecor GW and Cochran W.C (1997):

Statistical Methods, $7^{\text {th }}$ Ed. Oxford and J.B.H. Publishing Co.,504.

Sucharzewska D; Stochmal A; Oleszek W (2003):

The effect of Yucca schidigera extract on the physical structure and on the oxidative stability of sugar- candy foam products, Lebensmit. Wiss. Technol,36,3,347-351.

Szczesniak A; Brandt $M$ and Freidman H (1963):

Development of standard rating scales for mechanical parameters and correlation between the objective and sensory texture measurements, Food Tech, 22,50 .

Tiemstra P J (1964):

Marshmallows, FoodTechnol,18,125.

\section{Tom Clifford, Glyn H; Daniel} JW and Emma J. S (2015):

The Potential Benefits of Red Beet Roots Supplementation in Health and Disease.Nutrients 2015,7,2801-2822.

Utomo BSB; Darmawan M; Rahman AH and Ardi D.T(2014):

Physicochemical properties and sensory evaluation of jelly candy made from different ratio of carrageenan and konjac, 
Evaluation of Sensory, Physicochemical Changes of Marshmallow (Children Candy) by Addition Natural colors

Nesreen. M. El.Said Ali, Samia.A.Al-Askalany, and Hana.M.Ghandor.

Squalen, Bulletin of Marine and Fisheries Postharvest and Biotechnology,9,1,2534.

Velisek J (2002):

Chemiepotravin, $1^{\text {st }}$ ed., OSSIS, Tabor(in Czech).

\section{Von-Loesecke KW(1955):}

Drying and dehydration of food,Reinholdpublishing corporation New York Chapmanand Hall Ltd., London.

Watts BM; Ylimaki GL; Jeffery LE and Elias LG(1989):

Basic Sensory Methods for Food Evaluation,
International Development Research Center ,Ottawa, Cnada,60-63.

\section{Zhao YI and Zhao Y (2007):}

Berry fruit, value-added products for health promotion,(Ed.), NW (USA): CRC Press0-84935802-7.

(www.halalexpertise.com/ge latin).

www.Herbwisdom.com/Mar shmallow/Althaea or marshmallow-knowledge encyclopedia. 
Evaluation of Sensory, Physicochemical Changes of Marshmallow (Children Candy) by Addition Natural colors

Nesreen. M. El.Said Ali, Samia.A.Al-Askalany, and Hana.M.Ghandor.

Table (1): Main Physical Parameters and Chemical Composition of Marshmallows Products (soft candies)

\begin{tabular}{|c|c|c|c|c|c|c|c|c|}
\hline \multirow[t]{2}{*}{ Samples } & \multirow{2}{*}{$\begin{array}{c}\text { Moist } \\
\text { ure } \\
\text { Conte } \\
\text { nt. } \\
(\%) .\end{array}$} & \multirow{2}{*}{$\begin{array}{c}\text { Total } \\
\text { solids } \\
\text { (TS). } \\
(\%) .\end{array}$} & \multirow{2}{*}{$\begin{array}{c}\text { Colors Index } \\
(420 \mathrm{~nm}) .\end{array}$} & \multicolumn{2}{|c|}{ Identification Colors } & \multirow{2}{*}{$\begin{array}{c}\text { Fibe } \\
\text { rs } \\
(\%)\end{array}$} & \multirow{2}{*}{$\begin{array}{c}\text { Sucro } \\
\text { se } \\
(\%)\end{array}$} & \multirow{2}{*}{$\begin{array}{c}\text { Total } \\
\text { Sugar. } \\
(\%)\end{array}$} \\
\hline & & & & $\begin{array}{l}\text { Yellow(400- } \\
480 \mathrm{~nm}) . \\
(300 / 350-600 \mathrm{~nm}) .\end{array}$ & $\begin{array}{c}\text { Red (500- } \\
550 \mathrm{~nm}) . \\
(500-600 \mathrm{~nm}) .\end{array}$ & & & \\
\hline $\begin{array}{l}\text { Imported } \\
\text { Cont.,(1) }\end{array}$ & 12 & 88 & $\begin{array}{c}1.805 / 0490 / \\
0.119\end{array}$ & $\begin{array}{l}1.918(433 \mathrm{~nm}) / 2.48 \\
7(302 \mathrm{~nm})\end{array}$ & $\begin{array}{c}0,290 \\
(513 \mathrm{~nm})\end{array}$ & $\mathbf{0 . 0}$ & 3.21 & 11.10 \\
\hline $\begin{array}{l}\text { Local } \\
\text { Cont.,.(2) }\end{array}$ & 13 & 87 & 0.480 & ND & ND & 0.0 & 3.20 & 12.36 \\
\hline Blank & 11.07 & 88.93 & 0.072 . & ND & ND & 0.0 & 4.41 & 11.94 \\
\hline $\begin{array}{l}* * * \text { Golden } \\
\text { Berry. }\end{array}$ & 14.26 & 85.74 & 0.355 . & $0.084(419 \mathrm{~nm})$. & ND & 0.0 & 3.58 & 12.42 \\
\hline $\begin{array}{l}* \text { Red Beet } \\
\text { Root (a). }\end{array}$ & 16.08 & 83.92 & 0.284 & ND & $\begin{array}{c}0.470 \\
(540 \mathrm{~nm})\end{array}$ & 0.0 & 2.52 & 10.97 \\
\hline $\begin{array}{l}* * \text { Red } \\
\text { Beet Root } \\
\text { (b). }\end{array}$ & 11.85 & 88.15 & 0.085 . & ND & $\begin{array}{c}0.180 \\
(547 \mathrm{~nm})\end{array}$ & 0.0 & 1.99 & 10.81 \\
\hline
\end{tabular}

* (a)Beet Root as (juice). ***Golden Berry (100\%) / [red beet-roots juice/ puree; (golden berry (50\%)/red beet-roots $(50 \%)]$.

**(b) Beet Root as (puree).

Table (2) Total Antioxidants Activity/Minerals in Marshmallows Products (dry weight basis)

\begin{tabular}{|l|c|c|c|c|}
\hline Parameters. & \multirow{2}{*}{$\begin{array}{c}\text { Antioxidant } \\
\text { Activity. } \\
\text { Treatments. }\end{array}$} & \multicolumn{3}{|c|}{ Minerals (mg/kg). } \\
\cline { 3 - 5 } & (DPPH \%). & & $\mathrm{Si}$ & Ca \\
\hline Imported cont., (1). & 30.53 & 1.076 & 67.8 & $\mathbf{2 0 2 . 9}$ \\
\hline Local Cont.,(2). & 32.57 & 7.067 & 100 & $\mathbf{7 2 6 . 4}$ \\
\hline Blank. & 36.23 & 0.044 & 115.3 & $\mathbf{2 8 7 . 2}$ \\
\hline ***Golden Berry. & 44.87 & 0.074 & 81.2 & $\mathbf{2 7 5 . 9}$ \\
\hline *Red Beet Root (a). & 32.76 & 0.060 & 84.032 & $\mathbf{2 9 9 . 2}$ \\
\hline **Red Beet Root (b). & $\mathbf{4 1 . 2 1}$ & $\mathbf{0 . 0 7 4}$ & $\mathbf{9 0 . 0 3 5}$ & $\mathbf{3 1 9 . 8}$ \\
\hline
\end{tabular}

*(a)Red Beet Root as (juice).***Golden Berry $(100 \%) /[$ red beet-roots juice/ puree; (golden berry $(50 \%) /$ red beet-roots (50\%)].

**(b)Red Beet Root as (puree). 
Evaluation of Sensory, Physicochemical Changes of Marshmallow (Children Candy) by Addition Natural colors

Nesreen. M. El.Said Ali, Samia.A.Al-Askalany, and Hana.M.Ghandor.

\section{Table (3) Textural Attributes such as Texture Profile Parameters/Water} Activity for Marshmallows Products

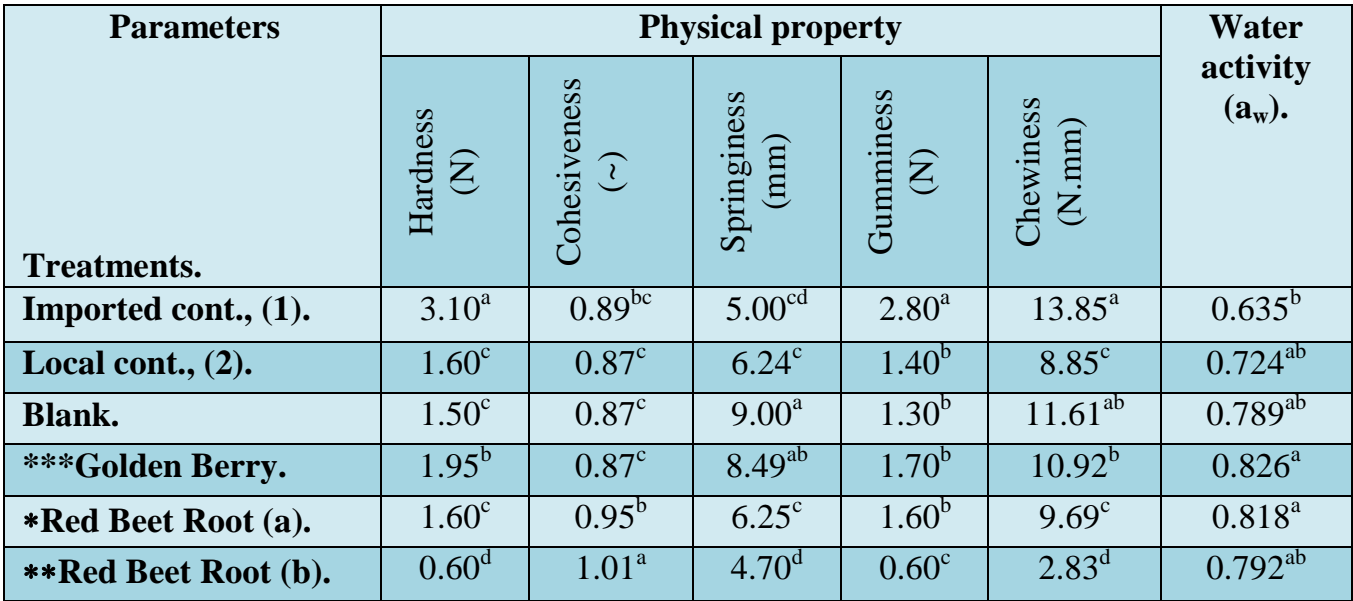

*Means followed by different letters in the same column are significantly different by Duncan's multiple tests $(\mathrm{p}<0.05)$.

$*($ a)Beet Root as (juice).***Golden Berry $(100 \%) /[$ red beet-roots juice/ puree; (golden berry (50\%)/red beetroots $(50 \%)$ ].

**(b) Beet Root as (puree).****N: Newton; m.m: Millimeter; N.m.m: Newton millimeter

Table (4) Reconstitution Ratio (\%) of Samples for Marshmallows Products at Ambient Temp., $\left( \pm 25^{\circ} \mathrm{C}\right)$.

\begin{tabular}{|l|c|c|c|c|c|c|}
\hline $\begin{array}{l}\text { Rehyd.,/Time (every } \\
1 \text { hr.). }\end{array}$ & $\mathbf{1}$ hr. & $\mathbf{2}$ hrs. & $\mathbf{3}$ hrs. & $\mathbf{4}$ hrs. & $\mathbf{5}$ hrs. & $\mathbf{6}$ hrs. \\
Treatments. & & & & & \\
\hline Imported Cont., (1). & $127.56^{\mathrm{a}}$ & $138.95^{\mathrm{a}}$ & $142.60^{\mathrm{a}}$ & $146.24^{\mathrm{a}}$ & $146.70^{\mathrm{a}}$ & $150.80^{\mathrm{a}}$ \\
\hline Local Cont., (2). & $101.55^{\mathrm{bc}}$ & $83.51^{\mathrm{bc}}$ & $69.24^{\mathrm{c}}$ & $56.77^{\mathrm{b}}$ & $42.39^{\mathrm{b}}$ & $33.19^{\mathrm{b}}$ \\
\hline Blank. & $90.23^{\mathrm{c}}$ & $86.67^{\mathrm{bc}}$ & $77.82^{\mathrm{bc}}$ & $67.47^{\mathrm{b}}$ & $57.13^{\mathrm{b}}$ & $47.59^{\mathrm{b}}$ \\
\hline **Golden Berry. & $83.54^{\mathrm{cd}}$ & $69.37^{\mathrm{c}}$ & $56.57^{\mathrm{c}}$ & $47.54^{\mathrm{b}}$ & $41.26^{\mathrm{b}}$ & $34.86^{\mathrm{b}}$ \\
\hline $\begin{array}{l}\text { *Red Beet Root } \\
\text { (Juice). }\end{array}$ & $91.76^{\mathrm{c}}$ & $76.26^{\mathrm{c}}$ & $68.02^{\mathrm{c}}$ & $53.51^{\mathrm{b}}$ & $43.42^{\mathrm{b}}$ & $34.07^{\mathrm{b}}$ \\
\hline $\begin{array}{l}\text { **Red Beet Root } \\
\text { (puree). }\end{array}$ & $73.99^{\mathrm{d}}$ & $33.92^{\mathrm{d}}$ & $26.26^{\mathrm{d}}$ & $16.58^{\mathrm{c}}$ & $3.39^{\mathrm{c}}$ & $0.88^{\mathrm{c}}$ \\
\hline
\end{tabular}

*Means followed by different letters in the same column are significantly different by Duncan's multiple test $(\mathrm{p}<0.05)$.

*(a)Beet Root as (juice).***Golden Berry (100\%) /[red beet-roots juice/ puree ;(golden berry (50\%)/red beetroots $(50 \%)]$.

**(b) Beet Root as (puree). 
Evaluation of Sensory, Physicochemical Changes of Marshmallow (Children Candy) by Addition Natural colors

Nesreen. M. El.Said Ali, Samia.A.Al-Askalany, and Hana.M.Ghandor.

Table (5) Sensory Evaluation of Different Suggestion Marshmallow

\begin{tabular}{|l|c|c|c|c|c|}
\hline \multicolumn{1}{|c|}{ Samples. } & Color & Taste & Odor & Texture & Acceptability \\
\hline Imported Cont.,(1) & $8.17^{\mathrm{a}}$ & $7.25^{\mathrm{ab}}$ & $7.25^{\mathrm{a}}$ & $7.58^{\mathrm{ab}}$ & $8.00^{\mathrm{a}}$ \\
Local Cont.(,2) & $8.00^{\mathrm{a}}$ & $8.33^{\mathrm{a}}$ & $7.67^{\mathrm{a}}$ & $8.25^{\mathrm{a}}$ & $7.67^{\mathrm{a}}$ \\
Blank. & $7.17^{\mathrm{a}}$ & $6.75^{\mathrm{ab}}$ & $6.75^{\mathrm{ab}}$ & $7.00^{\mathrm{ab}}$ & $7.08^{\mathrm{a}}$ \\
***Golden Berry. & $7.75^{\mathrm{a}}$ & $6.67^{\mathrm{ab}}$ & $6.42^{\mathrm{ab}}$ & $6.00^{\mathrm{bc}}$ & $7.25^{\mathrm{a}}$ \\
*Red Beet Root (a). & $7.83^{\mathrm{a}}$ & $7.25^{\mathrm{ab}}$ & $7.17^{\mathrm{ab}}$ & $7.25^{\mathrm{ab}}$ & $7.08^{\mathrm{a}}$ \\
**Red Beet Root (b). & $7.42^{\mathrm{a}}$ & $5.83^{\mathrm{b}}$ & $5.50^{\mathrm{b}}$ & $4.67^{\mathrm{c}}$ & $4.58^{\mathrm{b}}$ \\
\hline
\end{tabular}

Each mean value, within the same column, followed by the same letter is not significantly different at 0.05 levels.

$*($ a)Beet Root as (juice).***Golden Berry $(100 \%) /[$ red beet-roots juice/ puree; (golden berry $(50 \%) /$ red beet-roots $(50 \%)]$.

**(b) Beet Root as (puree). 


\section{تقييم الخواص الحسية والتغيرات الفيزيوكيميائية للمارشيملو ( حلوى الاطفال) بإضافة الألوان الطبيعية الطئية}

نسرين محمد السعيد على، 1سامية على العسقلانى، 2حنان محمد الغندور.1 1

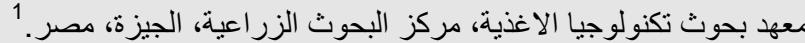
المركز الاقليمى للاغذية والاعلاف.

بالاونة الاخبرة ،تجه المستهكون الى شراء الهنتجات الغذائية من المصادر الطبيعية

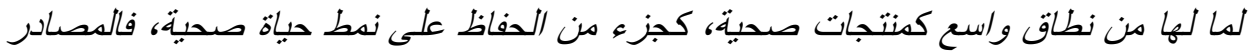

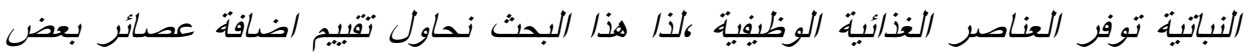

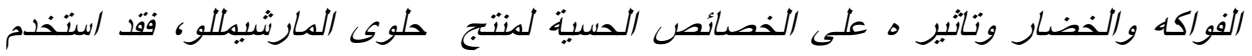

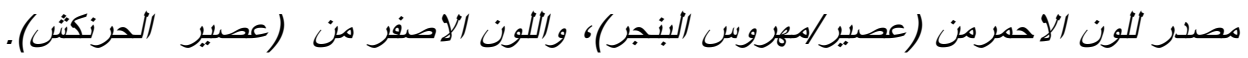

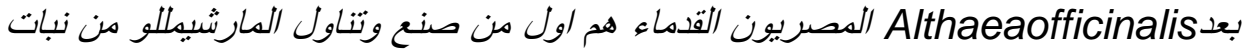

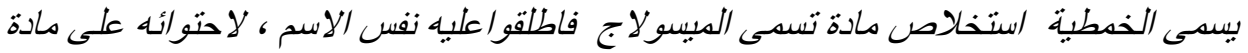

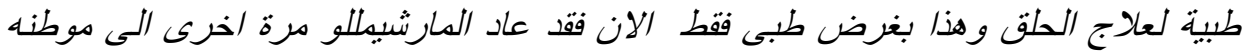

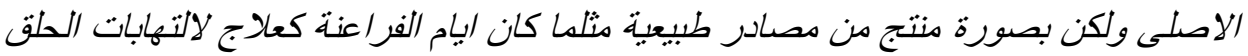

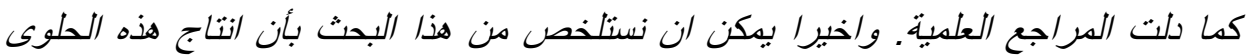

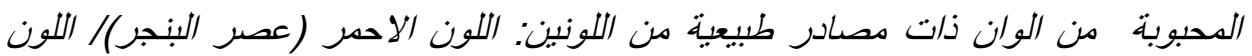

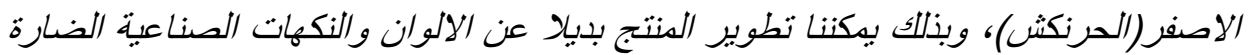

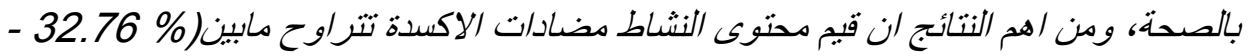

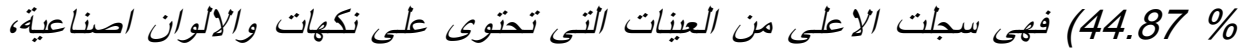

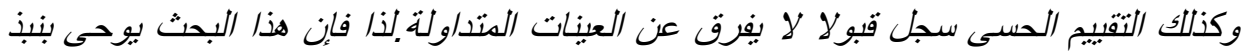
استخدام الألوان الصناعية الضارة بالصحة ، خاصة تلك الك الدستخدمة فى تلوبن حلوى الأطفال الدستهلك الاول لتلك الدنتجات الدلونة بتلك حلوى الدارشيبللو.

الكلمات المفتاحية: حلوى المارشبيلو - الالوان من مصادر طبيعية ( البنجر - الحرنكش) 